\title{
Modernization of Farmer's Managed Irrigation Systems in Nepal
}

\section{Achyut Man Singh}

Achyut Man Singh

\begin{abstract}
The irrigation infrastructures in Farmer's Managed I rrigation Systems (FMIS) of Nepal were mostly built from the local materials of mud, stone, and forest products with rudimentary traditional methods, practiced over many centuries. These systems are operated and maintained solely by the community farmers or an individual family. The Nepal Irrigation Sector Project (NISP), funded under the credit assistances of the World Bank, sponsored the modernization of these FMIS in the three western regions of Nepal from 1998 to 2004. The paper gives an account of the infrastructures built under the project to modernize the FMIS, and presents some facts about the impacts of the assistances to FMIS in relieving problems faced by farmers. The structures in the FMIS differ nominally according to the ecological region, due to the terrain and characteristics of the conveyance systems. In the hills, generally, lining and cross drainage structures are common; whereas, in the Terai, it is mostly the headworks structure due to lack of traditional materials as shrubs and forest products. The NISP assisted these FMIS with the participation of the users and their contribution in the civil works from seven to 15 percent. The users were involved in the design and construction of the infrastructures from the very initiation of the schemes. The project had good impacts on system performance and, thus, in agriculture production.
\end{abstract}

Key words: FMIS, irrigation, participatory development, water distribution, modernization, Nepal

\section{Background}

耳armer's Managed Irrigation Systems (FMIS) have $\perp$ prevailed in Nepal for many centuries. These systems are operated and maintained solely by the community farmers or an individual family. The construction of these small to large FMIS in hills and Terai in the past used to be done by a special community. They were expert in construction skills and indigenous technology to determine the alignment and slope of the canal. In Nepal's western hills they are the 'Agri' community and local landlords, whereas in the Terai the ethnic Tharu community are other experts in canal construction as well as in the operation of the systems. The 'Agri' people were capable of building side tunnels in the hills to avoid instability and large excavation through rocky areas. Examples of the canal constructions by these communities are found in many FMIS systems, including: Raj Kulo of Argali, and Chherlung of Palpa District, the Gyandi Irrigation system of Parbat District, and many others. Special features of traditional FMIS in the high mountain, mid-hills and lowland Terai of Nepal are as follows:

\section{High Mountain}

Usually the intake diversions are of rock fill with mud mortar walls, and canals have slate lining with mud mortar base. A traditional water reservoir is built in the proximity of the village. Traditional water reservoir or tank generally has a clay lining to prevent leakage. Highly porous strata along the canal alignment cause these traditional canals to leak profusely, so the farmers use a high flow inlet in the canal from the source and only about $10 \%$ of the flow is received at the actual command area. These systems have been modernized with HDP pipe conveyance and plastic lining.
Mid-Hills

The traditional FMIS in the mid-hills are comprised of simple brush wood diversion and open earthen canal systems up to the command area. Farmers usually utilize mud and shrubs to control leakages in the canal systems. Modernization of the irrigation systems has improved its intake structures, canal lining, and cross drainage structures.

\section{Terai}

In the Terai lowlands the diversion structures are usually built with an earthen bund with shrubs, logs, and stones where available. All thecanal systems are mostly open earthen section networks with division structures made with logs, shrubs and woods. Praganna Irrigation system of Dang Deukhuri of Nepal provides a good example of utilization of the local indigenous material, which has caused the depletion of the adjacent forest area. Due to the general depletion of the forest products, the farmers were in great difficulty in maintaining the diversion bund. Paddy straw and muds also were used at many places to maintain it. These methods were also practices in the Siyari Irrigation system of Rupandehi District, which has now been converted into concrete weir for diversion under the Nepal Irrigation Sector Project (NISP). ${ }^{1}$ Modernization of these systems includes permanent concrete diversion head works and masonry structures for bifurcation and division structures.

The NISP in Nepal's western region has endeavored to modernize the FMIS in all the three ecological regions. Under this project the intake types usually adopted are simple side intakes with a temporary diversion weir in hills, and gabion weir or concrete weir in the Terai regions. Two barrage structures also are constructed in Kapilvastu District. 
Summary assessment of the physical achievement indicates that $581 \mathrm{~km}$ of total canal length was considered in the rehabilitation schemes. The improvement works included $108.5 \mathrm{~km}$ long masonry lining, $16.84 \mathrm{~km}$ concrete lining, and $24.02 \mathrm{~km}$ HDP pipe conveyance systems. On infrastructure development works altogether 175 intake or H/Ws, 834 conveyances, 401 trail or road crossings, 364 distribution structures, and 51 other structures were built under the NISP.

\section{Objectives and Methodology}

A format for collecting data on the physical improvement works was prepared by the technical assistance (TA) team and was circulated to all cost centers of the western region under the Nepal's Department of Irrigation (DOI). The format was fulfilled at large by the division offices, so most of the data were received at the TA office. However, some subprojects, especially the Irrigation Line of Credit (ILC) carry over ones, do not have data, as these are missing at the cost centers. The available data were compiled and analyzed to give a comprehensive picture on the physical achievements under the NISP.

The primary objective of the assessment on the physical part of the NISP is to identify and quantify the types of structures built for intake, conveyance, distribution, and other. In addition, irrigation coverage by the project during the monsoon, winter, and spring seasons were also investigated.

The questionnaire used for the study has the following indicators for analysis:

1. Irrigation coverage in percentage - monsoon, winter, and spring seasons.

2. Total canal length $(\mathrm{km})$.

3. Intake Type-diversion structure built.

4. Lined canal length (m)-masonry, concrete, and HDP pipe.

5. Infrastructure developments such as: break pressure tank, drop structure, super passage, foot bridge, culvert, aqueduct, bifurcation, distribution, escape, desilting basin, outlets, siphon, and branch canal.

The division offices supplied the data from their records and some data were abstracted from the sub-project completion reports.

\section{Irrigation Coverage}

Distinctly irrigation coverage depends on the ecological region due to the climatic and temperature regime. In the high mountains, the cropping pattern is mostly mono-crop with hardly two crops with summer and in spring season. During winter it is generally under snow cover and has a sub-zero temperature regime.
In the mid-hills and lowland Terai there are possibilities of three crops a year, if water availability is assured and guaranteed through round the year. Taking the average of the districts according to the ecological regions, the summary of the irrigation coverage made by the project is assessed in Table 1.

\begin{tabular}{|c|c|c|c|}
\hline Ecological Region & Monsoon & Winter & Spring \\
\hline High Mountain & 97 & - & 51 \\
\hline Mid Hills & 96 & 67 & 40 \\
\hline Terai & 97 & 40 & 37 \\
\hline Overall average & $\mathbf{9 7}$ & $\mathbf{5 2}$ & $\mathbf{4 3}$ \\
\hline
\end{tabular}

Table 1. Irrigation Coverage in Percentages According to Ecological Zone.

\section{Infrastructures Developments}

\section{Intakestructures}

In irrigation systems theintake or head works is the most vital structure in diverting the river water for irrigation. The types of the intake structures vary according to the river type, its characteristics, and river morphology. The river characteristics in its aggradation and degradation trend determine the type of the intake structure. Inappropriate selection of intake structure sometimes results to failure of the whole system.

In hill irrigation the experiences of the Department of Irrigation have given many fruitful decisions in this aspect. A general lesson learned is that simple side intake should be constructed in hilly streams that have a steep bed slope and may carry a large debris flow. The river diversion is made of a flexible temporary gabion weir or simple brush wood weir, due to the unpredictable nature of the streams that sometimes degrade or aggrades substantially according to the geological events in its catchments.

An example is the Chhangchhangdi scheme of Syangja District, which has failed due to degradation of the river bed. Similar cases are observed at the Arutar irrigation scheme of Gorkha District. Taking lessons from previous failures, intake design is considered as suitable to the site specific. In such cases, trench type headworks have been designed at the Mahendrakot scheme of Kapilvastu District, where the stream was wild and used to carry large boulders in its bed load.

In summary, collection chambers or rock fill diversions

\begin{tabular}{|l|c|c|c|c|c|}
\hline $\begin{array}{c}\text { Ecological } \\
\text { Region }\end{array}$ & $\begin{array}{c}\text { Concrete/ Masonry } \\
\text { Chamber }\end{array}$ & $\begin{array}{c}\text { Side } \\
\text { Intake }\end{array}$ & $\begin{array}{c}\text { Gabion } \\
\text { Weir }\end{array}$ & $\begin{array}{c}\text { Concrete Weir/ } \\
\text { Barrage }\end{array}$ & $\begin{array}{c}\text { Trash Rack/ } \\
\text { Trench }\end{array}$ \\
\hline High Mountain & 5 & 6 & 6 & - & - \\
\hline Mid Hills & 1 & 116 & 8 & 4 & - \\
\hline Terai & - & 12 & - & 16 & 1 \\
\hline Total & $\mathbf{6}$ & $\mathbf{1 3 4}$ & $\mathbf{1 4}$ & $\mathbf{2 0}$ & $\mathbf{1}$ \\
\hline
\end{tabular}

Table 2. Intake Types Constructed in the Western Region. 
are generally built at in high mountain sites, side intakes with gabion weirs are built in the mid-hills, and concrete weirs are most commonly built in the Terai regions. The details of the types and their numbers built are summarized in Table 2.

\section{Canal lining}

Under lining, it is grouped into masonry, concrete lining and HDP pipe use. It has been a general practice in the hills that stone masonry linings are provided to check seepage from the canals. Usually a 10 to $15 \mathrm{~cm}$ thick concrete base is prepared and stone masonry walls 20 to $30 \mathrm{~cm}$ thick are constructed on the base. For small canal sections this lining method is expensive and also occupies a wide canal width, which is not easily available on hill slopes. In addition, masonry linings generally leak if the cement mortar is not placed in proper way. It has also been observed that cement mortar generally weathers after two to three years of use under water. Maintenance is also critical to the farmers due to unavailability of cement in a few cases. The stone masonry lining is very common and popular among the farmers, however, due to easily available materials (stone and sand) at the sites, and local skill labor is available from the villages.

There has been an intense debate in the irrigation department about the use of lining materials in hilly canals. It was recommended that as far as possible concrete linings with nominal reinforcement should be used in the hills, instead of stone masonry lining. This decision was formally made during FY2000/ 01.

HDP pipe conveyance structures are common in the high mountain zone as high heads are available to convey water from source to command area. HDP pipe is easy to handle and to transport by air.

In the mid-hills, HDP pipe is common in crossing large valleys and for drainage of canal water.

A summary of the works carried out under lining heads is given in Table 3 .

\begin{tabular}{|l|l|l|l|}
\hline \multirow{2}{*}{ Ecological Region } & \multicolumn{3}{|c|}{ Lining Works in Meter } \\
\cline { 2 - 4 } High Mountain & Masonry & Concrete & HDP Pipes \\
\hline Mid Hills & 2,800 & 2,200 & 13,041 \\
\hline \multirow{2}{*}{ Terai } & 93,555 & 13,535 & 10,975 \\
\hline \multirow{2}{*}{ Total } & 12,144 & 1,110 & - \\
\hline
\end{tabular}

Table 3. Type of Lining Used According to Ecological Zone.

Conveyance structures

Under this category of structures, break pressure tank, drops, aqueduct, syphon, and super passage structures are built. Break pressure tanks are built in the HDP pipe conveyance to release the excess energy due to high head available at the canal.

A summary of these structures built is given in Table 4 .

As can be seen from Table 3 and 4, conveyance structures in the high mountain are comprised mostly of BPT and HDP pipe.

\begin{tabular}{|l|c|c|c|c|c|}
\hline $\begin{array}{c}\text { Ecological } \\
\text { Region }\end{array}$ & $\begin{array}{c}\text { Break } \\
\text { Pressure } \\
\text { Tank }\end{array}$ & $\begin{array}{c}\text { Drop } \\
\text { structures }\end{array}$ & Aqueduct & $\begin{array}{c}\text { Super Pas- } \\
\text { sage }\end{array}$ & Syphon \\
\hline High Mountain & 42 & 2 & - & 2 & - \\
\hline Mid Hills & 14 & 200 & 92 & 337 & - \\
\hline Terai & - & 85 & 13 & 47 & 1 \\
\hline Total & $\mathbf{5 6}$ & $\mathbf{2 8 7}$ & $\mathbf{1 0 5}$ & $\mathbf{3 8 6}$ & $\mathbf{1}$ \\
\hline
\end{tabular}

Table 4. Conveyance Structures Constructed in the Western Region,

\section{Trail and road crossing structures}

Foot bridge structures were also built to allow animals and people to cross the canals, and culverts were built to allow vehicular traffic to cross.

A summary of the structures built is given in Table 5 .

\begin{tabular}{|l|c|c|}
\hline Ecological Region & Footbridge & Road culverts \\
\hline High Mountain & 8 & - \\
\hline Mid Hills & 298 & 16 \\
\hline Terai & 24 & 55 \\
\hline Total & $\mathbf{3 3 0}$ & $\mathbf{7 1}$ \\
\hline
\end{tabular}

Table 5. Trail and Road Crossing Structures.

\section{Distribution structures}

Distribution structures are constructed mostly on the demand of the farmers, as required by their water management practices. The engineers take special care in selecting thestructures suitableto match their requirements. In general, proportionate weir divisors are constructed for division among the groups. In the Bhanusera Irrigation system of Tanahun District, the farmers apply rotational distribution among the shareholders of the water utilization system. The main canal is diverted to seven branch canals at a place Satmuhane (meaning 'seven mouths'). The whole flow is diverted into one canal at a time and time periods are allocated for water delivery. The NISP recently built a division structure to allow them to distribute in rotation. Under this category, bifurcation or trifurcation structures, division boxes, and outlets are considered.

A summary of the structures built is given in Table 6 .

\begin{tabular}{|l|c|c|c|c|}
\hline $\begin{array}{c}\text { Ecological } \\
\text { Region }\end{array}$ & Bifurcation & $\begin{array}{c}\text { Division } \\
\text { / distribution } \\
\text { boxes }\end{array}$ & $\begin{array}{c}\text { Branch } \\
\text { Canals }\end{array}$ & Outlets \\
\hline High Mountain & - & 19 & - & - \\
\hline Mid Hills & 7 & 171 & 96 & 44 \\
\hline Terai & 16 & 70 & 80 & 19 \\
\hline Total & $\mathbf{2 3}$ & $\mathbf{2 6 0}$ & $\mathbf{1 7 6}$ & $\mathbf{6 3}$ \\
\hline
\end{tabular}

Table 6. Distribution Structures. 
The study also asked about the number of branch canals in the developed systems, and it was reported that 96 branch canals exist in the mid-hills, and 80 in the Terai lowlands. The records indicate that the NISP has contributed to improving and supporting the water management facility of the FMIS.

\section{Other structures}

In addition to the above structures, other type of structures as escape, collection chamber and desilting basin were also constructed. These are summarized in Table 7.

\begin{tabular}{|l|c|c|c|}
\hline Ecological Region & Escape & $\begin{array}{l}\text { Desilting } \\
\text { Basin }\end{array}$ & $\begin{array}{l}\text { Collection } \\
\text { Chamber }\end{array}$ \\
\hline High Mountain & - & 2 & 8 \\
\hline Mid Hills & 28 & 4 & - \\
\hline Terai & 7 & 1 & - \\
\hline Total & $\mathbf{3 5}$ & $\mathbf{7}$ & $\mathbf{8}$ \\
\hline
\end{tabular}

Table 7. Other Structures.

\section{Lessons Learned}

Assistance to improve the FMIS were initiated in the 1980s, when an ILC Pilot Project, Dhaulagiri Irrigation Development Project, and Irrigations Sector Project were implemented with financial assistance from the World Bank, the ILO, and the Asian Development Bank respectively. The mode of assistances to FMIS has always been in debate, as one school of thought argues to support the farmer's bare minimum to relieve their essential need only. This side of the debate pointed to sustainability after the assistance and maintenance problems. On the other hand, it was counterargued that the need related to environmental change and depletion of the indigenous forest products requires going for extensive engineering structures. It is essential that these systems also need modernization with essential engineering applied to the improvement works. However, the implementations in these projects have given clear directives that the development works should go in between these thoughts.

The engineering inputs for the modernization works must also consider the requirement as per site situation and the institutional set up of the local water users association must be strengthened to make them capable of managing the maintenance requirements. Nowadays farmers demand concrete lining instead of clay lining. The situation has changed quite a lot in those villages reached by gravel roads that are capable to use cement mortar.

Nepal has a wide range of river types varying from boulder stage in the hills to large braided or gravel bed rivers in the Terai. Types of intakes and diversion structures are selected on the basis of the characteristics of these rivers. It is generally observed that several Farmers' Managed Irrigation Schemes are tapped in series from the same source river. Diversion structures are temporary, built with earth, boulders, shrub and wood. The downstream users tap leakage from these diversion bunds. Equilibrium is traditionally established in theutilization of the water source for these systems. If a permanent diversion structure is built in any of these systems, the equilibrium of water usage will be disturbed, consequently creating serious water rights conflicts among FMIS. Hence, designers should consider these issues prior to finalizing diversion structure design.

Design approach for new irrigation schemes and rehabilitation schemes will be different in the appraisal and detailed design phase. For new construction schemes, the design is based on more rigorous investigations and survey to ensure reliability and sustainability. In hill irrigation schemes especially, newly built canal alignments are prone to slides and destabilisation due to freshly cut strata. Observation of conditions on nearby existing schemes can often provide insight as to likely problems that may be encountered,. And their potential solutions. The design approach for new construction schemes in the Terai is based on conventional methods and approaches.

For FMIS rehabilitation schemes, it is particularly the problem areas that need to be focused on for improvements. Experience gathered from the past construction works in the ILC and ISP programs reveals the following main problems raised by farmers regarding their FMIS.

In the hills and mountains-

- water acquisition and protection of intake structure from flash flood and river bed load

- seepage problems in the feeder and main systems

- siltation problems in the feeder canal

- landslides, bank failures

- river encroachment

- water distribution

- large river crossings

In the lowland Terai-

- abstraction from rivers

- canal bank overtopping

- siltation

- seepage

- canal side slope stability

- inundation from natural drainage and drainage from command area

- water distribution

To summarize, farmers' demands for assistance to hilly schemes generally include side intakes, lining and cross drainage structures. For mountain zones, it is by generally HDP pipe conveyances. In the Terai, it is mainly for diversion head works, cross drainage and other conveyance structures.

\section{Conclusions and Recommendations}

- Selection and design of appropriate structures in 
modernizing the FMIS should consider the prevailing systems and operation mode. The modernization works should be designed in such a way that their systems work smoothly and are easily adoptable by the farmers.

- In constructing a permanent diversion structure the designer must consider the water right issues among the users of the stream at the downstream side. To avoid water rights issues in the hills, simple side intake structures are constructed with their traditional diversion technique intact.

- The distribution structures should be designed to match the water management practice of the farmers prevailing in the systems, as these may vary system to system.

- Some useful maxims have been developed for effective design of FMIS in hilly areas of Nepal and are presented below. Many of these will also apply to Terai areas as well. ${ }^{2}$

Maxim 1. No matter how large or small a structure, farmers must always be consulted about thetype of structure they need and how they plan to operate and maintain it.

Maxim 2. When proposing a new design makes sure that traditional village practices are compatible with it. If not, forewarn the users of potential dangers.

Maxim 3. Accept traditionally proven and timetested local design concepts. Modify them if necessary but stay within limits acceptable to users by not imposing difficult operational procedures.

Maxim 4. Do not build structures that shift the responsibility for operation and maintenance to the Government and other external agencies.

Maxim 5. Designs must be made with repair and maintenance in mind. Whenever possible, the use of local materials in canal construction should be promoted. Transfer the technology and skills necessary for repair and maintenance of the system during the construction phase.

Maxim 6. Build small, strong civil works in the hills. Disturb stable slopes as little as possible.
Maxim 7. To understand the real problems, make field visits to see the system in operation under its most difficult situation. This will help in selecting a suitable design for solving the problem.

Maxim 8. Good quality control and workmanship are necessary to make full use of the strength and durability of imported construction materials (cement, steel and plastic).

Achyut Man Singh, BE (Civil), M. Sc. (Soil \& Water Management) from The Netherlands is an irrigation specialist. He served in the Nepal Department of Irrigation for 22 years, and 15 years in private sector mostly in the field of irrigation engineering. He served a number of assignments for the Asian Development Bank and the World Bank. At present, he is a consultant affiliated with the FAO/World Bank funded Nepal's Irrigation and Water Resources Management Project.

Corresponding Address: singham@wlink.com.np

\section{Notes}

1. The Nepal Irrigation Sector Project (NISP) was implemented in the three western regions of Nepal for assisting and modernizing the FMIS from 1998-2004, sponsored under credit assistances from the World Bank and Government of Nepal.

2. These maxims were developed by Basil J acob, Training Adviser, Capacity Building Project, ILO Special Public Works Program, Nepal in the early 1990s, and are taken from Yoder (1994).

\section{References}

DOI/NISP, 2004, Nepal Irrigation Sector Project, Project Completion Report, Kathmandu: Department of Irrigation, Nepal Irrigation Sector Project.

Yoder, Robert; 1994, Designing Irrigation Structures for Mountainous Environment: A Handbook of Experiences, Colombo, Sri Lanka: International Irrigation Management Institute (IMMI). •

\section{Typical Structures Built Under NISP in the Western Region of Nepal}

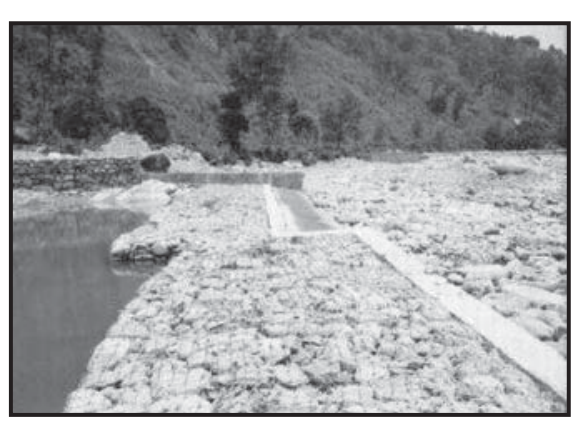

Side Intake at Upallow Dabaki, Kaski

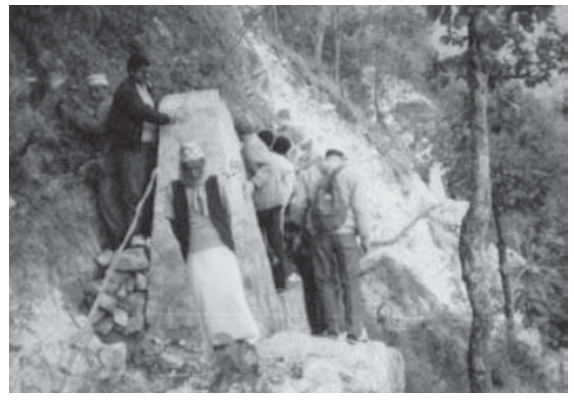

Super passage structure (Typical)

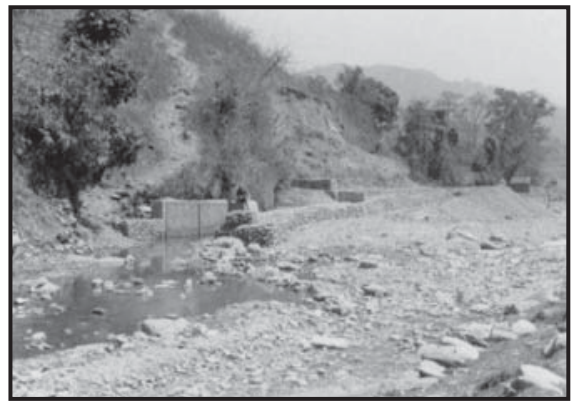

Trash Rack-Tyrolean Weir at Mahendrakot, Kapilvastu District 


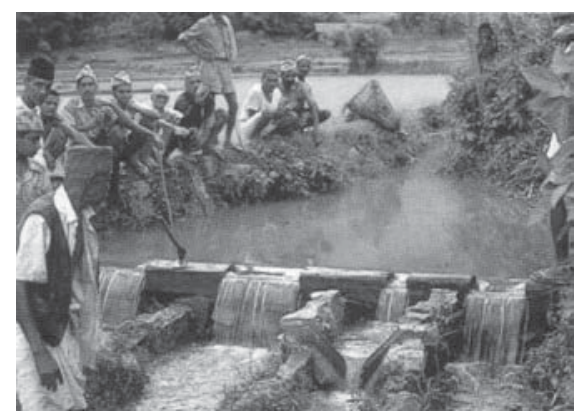

"Sancho" Proportionate Divisor of Raj Kulo of Palpa District

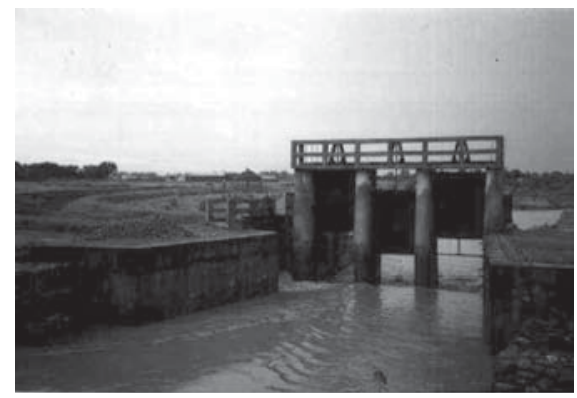

Barrage Structure at Ghagara, Rupandehi District

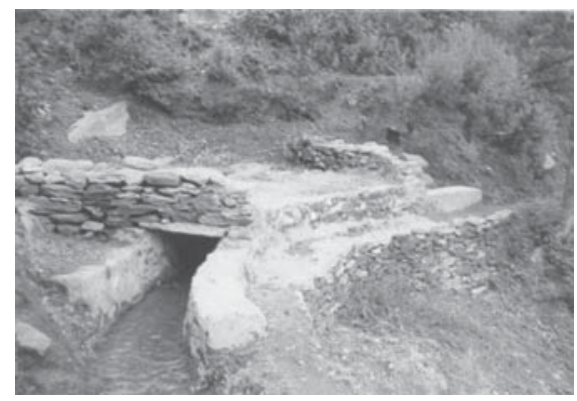

Super passage structure (Typical)

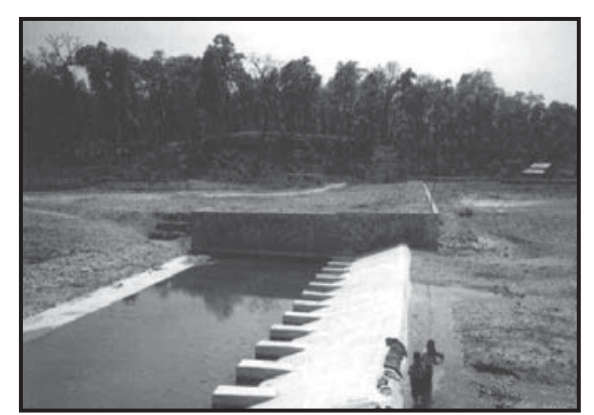

Concrete Weir at Kanchan, Rupandehi

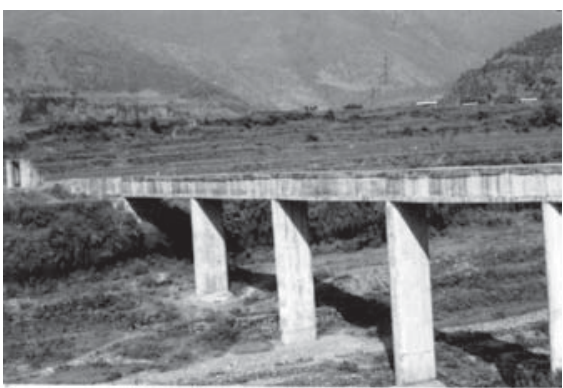

Aqueduct structure at Chapakot, Syangja District

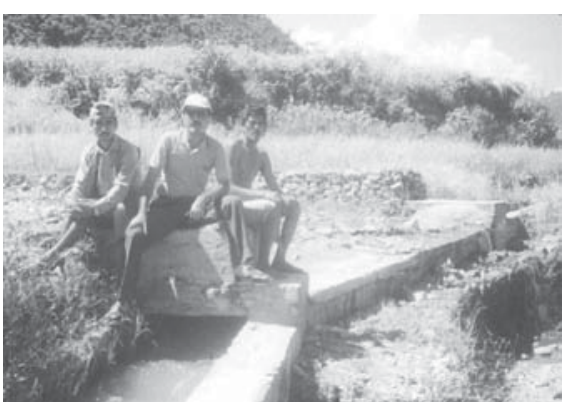

Suspended Pipe Crossing, Maryang Singh, Parbat District

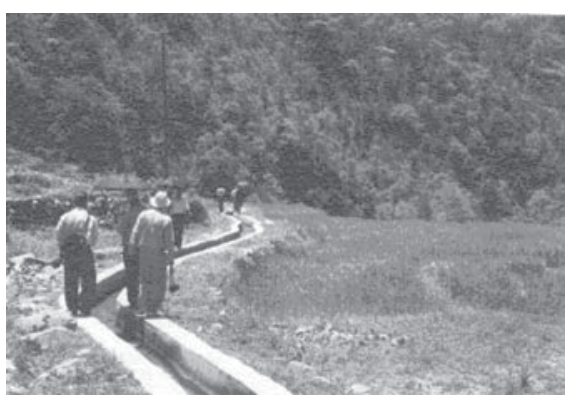

Canal Linning.

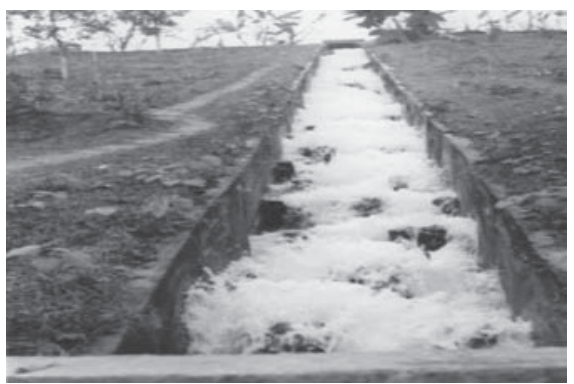

Dented Chute structure at Chapakot

\section{GALENDAR HYDROPOWER}

1-3 February 2010: Hydropower'10, 6th International Conference on hydropower. Location: Tromso, Norway. More Info: www.hydropower10.org/

2-13 February 2010: International Training Course on Small Hydropower Development. Location: Roorkee, India. More Info: www.iitr.ernet

25-28 February, 2010: IPS 2010- Building Partnerships for international power producers. Location: London, UK. More Info: www. internationalpowersummit.com

31 May- 17 June 2010: Hydropower and the Environment. Location: Trondheim, Norway. More Info: www.ich.no/ DynamicCourses.asp

27 September - 2 October 2010: Small Hydro Resources, Location: Trondheim, Norway. More Info: www.ich.no/ DynamicCourses.asp

25-29 October 2010: Risk Management in Hydropower Development, Location: Trondheim, Norway. More Info: www.ich.no/ DynamicCourses.asp

30 August - 3 September 2010, Contractual and Legal Framework in Hydropower Development, Location: Trondheim, Norway. More Info: www.ich.no/ DynamicCourses.asp; e mail : mail@ich.no 